\title{
Teaching style, learning motivation, and learning achievement: do they have significant and positive relationships?
}

\author{
Bagas Adi Atma ${ }^{1}$, Fatun Fatimah Azahra ${ }^{1}$, Ali Mustadi ${ }^{1}$, Colomeischi Aurora Adina ${ }^{2}$ \\ ${ }^{1}$ Universitas Negeri Yogyakarta. Jalan Colombo No. 1, Karangmalang, Yogyakarta 55281, Indonesia \\ ${ }^{2}$ Stefan cel Mare University of Suceava. Strada Universității 13, Suceava 720229, Romania \\ * Corresponding Author. E-mail: bagasadi.2019@student.uny.ac.id
}

Received: 29 June 2020; Revised: 30 August 2020; Accepted: 15 September 2020

\begin{abstract}
This study aims at determining whether there is a positive and significant relationship between three variables (teacher teaching style, learning motivation and learning achievement). The subjects in this research were 5th elementary school students in Saptosari sub-district, Gunungkidul district, with a total of 141 students. This research is correlational quantitative research with data collection using a questionnaire in the form of a research questionnaire containing a scale. The hypothesis in this correlational study used partial correlation analysis and simultaneous regression analysis. The analysis used is data description analysis and multiple linear analysis. The results showed that there was a significant and positive relationship between learning achievement and teaching style got a value of 0.546 with a relative contribution of $23 \%$. Meanwhile, learning motivation and learning achievement got a value of 0.462 with an effective contribution of $9 \%$ and the relation between teaching style and learning motivation on learning achievement show an $\mathrm{r}$ square value of 0.324 with a total contribution or effective contribution of $32 \%$. Based on the results, it showed that teaching style and learning motivation have a significant and positive relationship with learning achievement.
\end{abstract}

Keywords: the teacher's teaching style, learning motivation, learning achievement

How to Cite: Atma, B. A., Azahra, F. F., Mustadi, A., \& Adina, C.A. (2021). Teaching style, learning motivation, and learning achievement: Do they have significant and positive relationships?. Jurnal Prima Edukasia, $\quad 9(1), \quad$ 23-31. doi:https://doi.org/10.21831/jpe.v9i1.33770

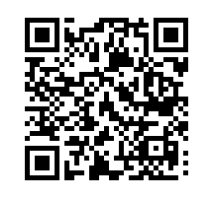

\section{Introduction}

Teachers are the second parents of students at school. As a role model for students at school, teachers should have qualified teaching skills. Then, as the most influential educational administration implementer in the implementation of education, teachers are responsible for the implementation of the teaching and learning process in schools. Law No. 14 of 2005 on Teachers and Lecturers states, "Teacher competencies cover pedagogical, personal, social, and professional competences obtained through professional education and these competencies are interrelated." Thus, in terms of pedagogical competence, teachers have to understand and master teaching skills in accordance with the field conditions. Gafoor and Babu (2012) describes teaching styles into five, namely, how teachers teach including the teaching behavior, how teachers organize teaching and the classroom environment, teaching styles and cognitive styles affect a person's teaching style, identifiable classroom behavior, and preferred ways of solving problems, completing assignments, and making decisions in the teaching process. Therefore, teaching style cannot be interpreted in a narrow sense as a way of conveying information or knowledge from the teacher to students but also includes all issues related to the learning process in the classroom. It was confirmed by Frunză (2014) who stated that teaching styles represent a constant concern in the area of education and communication and through teaching behavior. They are designed to create an atmosphere of emulation, reliable, and productive cooperation within the teaching staff." The teaching style which ideally involves students in two-way communication arises students' motivation to participate actively in the learning process.

However, the field conditions showed less variation in teaching styles used in the classroom as reported by Kompasiana.com with the headline of "The curriculum has been 2013, but the teaching style has not changed." It has been a concern for the educational institutions in this country in which it is 
Jurnal Prima Edukasia, 9 (1), 2021 - 24

Bagas Adi Atma, Fatun Fatimah Azahra, Ali Mustadi, Colomeischi Aurora Adina

required to develop and be able to compete with other countries. However, the conventional teaching style which is seen teaching as a "transfer of knowledge" has not changed in accordance with the current condition and students' background. The monotonous teaching style using lecturing results in students' lower motivation in learning. This condition affects the students' understanding and interest in learning. Thus, their learning achievement will be low.

In the education context, motivation is a crucial factor in helping educators improve learning (Williams \& Williams, 2011). When students are motivated, learning will be easy. However, motivating students to learn requires a challenging role for teachers and varied teaching styles and techniques to attract the students' interest. It is in line with Vărăşteanu and Iftime (2013), in which teachers have to be always aware of motivation and encouragement as a key to student active learning. Some teaching styles can be utilized in the teaching and learning process. Abbas and Hussain (2018) classifies teaching styles into five, namely, expert type, formal authority type, personal model type, facilitator type, and delegator type. Meanwhile, Ali et al. (2010) divides teaching styles into four, namely, classical, technological, personalized, and interactional teaching styles.

The use of varied teaching styles, besides being able to prevent students from boredom in learning and can generate motivation and improve their achievement. It is in accordance with Nir and Hameiri (2014) in which teaching styles and quality of teaching can have a positive impact on student motivation which results in better academic achievement and even can motivate students to learn and influence their attitudes. Idhaufi and Ashari (2017) stated that the use of varied teaching styles can prevent students from boredom in learning and make them feel more motivated to learn. In addition, when students enjoy and are motivated to learn, they will have a good attitude.

Some cases in primary school showed that students go to school because they have to go, not to learn, and pursue a better future so that they accept learning as the way it is. Students with positive attitudes will be more motivated to learn, while students with negative attitudes will hinder learning. This is in line with Cudney and Ezzell (2017) who states that motivation is an important factor in education because it encourages students to produce meaningful work and fosters a desire for lifelong learning. Learning motivation is an internal encouragement of a person to learn to reach optimal learning achievement. Students with high learning motivation will put aside undesired feelings to get satisfaction in the learning process. Further, Çelen et al. (2010) reported that students will learn a topic more easily if they want to understand the topic. Sardiman AM (2004) proposed some indicators that can be used to determine the strength of learning motivation, namely (1) perseverance in facing tasks, (2) persistence in facing difficulties (not easily discouraged), (3) showing interest in various adult problems, (4) preferring to work independently, (5) quickly getting bored of routine tasks, (6) being able to defend their opinion, (7) not easily letting go of what they believe in, and (8) enjoying finding and solving problems.

Learning motivation also affects the students' learning achievement as supported by (Hamdani, 2011) who explains two factors affecting learning achievement, namely, internal and external factors. The internal factor covers intelligence, physical, attitude, interest, talent, and motivation, while the external factor includes social and non-social environments. Further, he explained that in the social environment, teachers' roles externally affect students' learning achievement. Learning achievement apart from being supported by the teaching style used by the teacher (Nir \& Hameiri, 2014), also supported by students' motivation for learning (Sharma \& Sharma, 2018) in which for late childhood school students, motivation for academic achievement is important. Thus, students are stimulated to complete a task, achieve a goal or qualification level.

In some primary schools in Saptosari Sub-district, the researcher found a tendency of the use of conventional teaching styles without consideration of students' characteristics and differences. Further, the students looked bored and less enthusiastic about learning. Indeed, some teachers used certain styles to attract the students' interest in learning, but they seemed to memorize the materials and when students start getting bored, they used special tricks to bring back students' attention. Teachers support students who look serious to be the best in the classroom. Even though the competition is not always good, it is undeniable that primary school-age children always want to get the teacher's attention. Attractive teachers encourage students to be active in learning and responding to the teacher.

This study aims to determine the relationship between the independent variables (teaching style and learning motivation) and the dependent variable (learning achievement) of the fifth-grade students at state primary schools in Saptosari sub-district, Gunungkidul district. 
Jurnal Prima Edukasia, 9 (1), 2021 - 25

Bagas Adi Atma, Fatun Fatimah Azahra, Ali Mustadi, Colomeischi Aurora Adina

\section{Methods}

This correlational quantitative research aims to determine whether there is a positive and significant relationship between the independent variables of teaching style (X1) and learning motivation (X2) and the dependent variable of learning achievement (Y). The relation between the dependent and independent variables can be seen in the Figure 1.

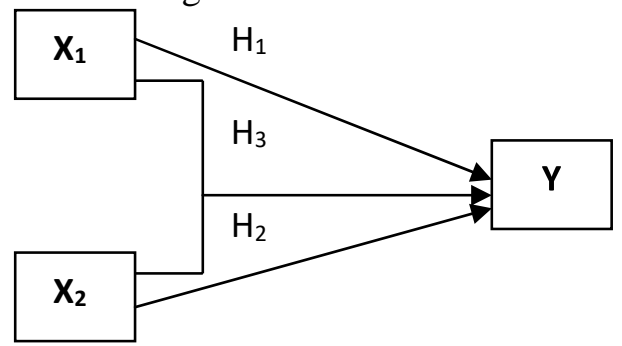

Figure 1. The relation between the dependent and independent variables

This research was conducted at primary schools in Saptosari sub-district, Gunungkidul District in December 2019. The population was all 5th-grade students of 13 primary schools in Saptosari subdistrict, Gunungkidul with a population of 220 students. Meanwhile, the sample was 141 students of the 5th-grade students Saptosari sub-district, Gunungkidul District selected using the Slovin Formula 1:

$n=\frac{N}{1+N e 2}$

The sample in this correlational study was selected using random sampling techniques (Creswell, 2012). The data were collected using a questionnaire with scales. The researcher handed the questionnaire to the homeroom teachers of each classroom and provided necessary explanations and instructions about the questionnaire. This study used a closed questionnaire to obtain data on teaching style (X1), learning motivation (X2), and learning achievement (Y) variables.

This quantitative research statistically analyzed the obtained data with partial correlation and simultaneous and regression analysis. Meanwhile, inferential statistics was carried out by analyzing sample data taken from a random population. The analysis was conducted to determine the achievement of research objectives using data description analysis and multiple linear analysis.

\section{Results and Discussions}

Prerequisite tests were conducted before testing the hypothesis to determine whether the data are feasible or not. The prerequisite test cover:

\section{Normality Test}

The normality test was to test whether the data were distributed normally or not with significance values of $>0.05$ (normally distributed) and $<0.05$ (not normally distributed). The result of the normality test can be seen in the Table 1 .

Table 1. The Normality Test

\begin{tabular}{cllll}
\hline No. & Variable & P-sig & Conclusion & Interpretation \\
\hline 1. & Teaching style & 0.093 & $\mathrm{p}>0.05$ & Normal \\
2. & Learning motivation & 0.200 & $\mathrm{p}>0.05$ & Normal \\
3. & Learning achievement & 0.200 & $\mathrm{p}>0.05$ & Normal \\
\hline
\end{tabular}

Based on the Table 1, all data were normally distributed with P-sig values of all variables higher than 0.05 .

\section{Linearity Test}

The linearity test was conducted for variable $\mathrm{X}_{1}$ and $\mathrm{Y}$ and variable $\mathrm{X}_{2}$ and $\mathrm{Y}$. If the deviation from the linearity value is higher than 0.05 , they have a significant relationship, otherwise, their relationship is not significant. The result of the linearity test can be seen in the Table 2 . 
Jurnal Prima Edukasia, 9 (1), 2021 - 26

Bagas Adi Atma, Fatun Fatimah Azahra, Ali Mustadi, Colomeischi Aurora Adina

Table 2. The Linearity Test

\begin{tabular}{cllll}
\hline No. & Variable & P-sig & Conclusion & Interpretation \\
\hline 1. & $\mathrm{X}_{1}$ and $\mathrm{Y}$ & 0.372 & P-sig $>0.05$ & Linear \\
2. & $\mathrm{X}_{2}$ and Y & 0.203 & P-sig $>0.05$ & Linear \\
\hline
\end{tabular}

Based on the Table 2, the P-sig value is $>0.05$, so it can be concluded that variable $\mathrm{X}_{1}$ and $\mathrm{Y}$ and variable $\mathrm{X}_{2}$ and variable $\mathrm{Y}$ have a linear relationship.

Multicollinearity Test

The multicollinearity was to find out whether the independent variables have a significant correlation in the regression model or not. It was based on the result of the Variance Inflation Factor (VIF) in which there is no correlation between independent variables with a Tolerance value of $>0.10$ and a VIF value of $<10.00$. The result of the multicollinearity test can be seen in the Table 3:

Table 3. The Multicollinearity Test

\begin{tabular}{clll}
\hline No. & Variable & Tolerance Value & VIF Value \\
\hline 1. & Teaching & 0.620 & 1.612 \\
2. & Motivation & 0.620 & 1.612 \\
\hline
\end{tabular}

Table 3 presents the tolerance value of $0.620>0.1$ and VIF value of $1.612<10$, so that there is no multicollinearity.

Hypothesis Test

The results of the prerequisite analysis showed that the research variables had met the requirements for further testing, namely the hypothesis test. The hypothesis test used partial correlation analysis and simultaneous regression analysis with SPSS version 23. The result of the hypothesis test can be seen in Table 4.

Tabel 4. The Hypothesis Test (Hypothesist 1 and Hypothesist 2)

\begin{tabular}{|c|c|c|c|c|c|c|}
\hline \multirow{2}{*}{ No. } & \multirow{2}{*}{ Partial relationship } & \multirow{2}{*}{ Control variable } & \multirow{2}{*}{ Correlation coefficient } & \multicolumn{2}{|c|}{ Tolerance } & \multirow{2}{*}{ Interpretation } \\
\hline & & & & P-count & $\mathrm{P}_{\text {-table }}$ & \\
\hline 1. & $\mathrm{r}_{1 \mathrm{y}}$ & $\mathrm{X}_{2}$ & 0.546 & 0.000 & 0.05 & (+) and significant $n$ \\
\hline 2. & $\mathrm{r}_{2 \mathrm{y}}$ & $\mathrm{X}_{1}$ & 0.462 & 0.000 & 0.05 & $(+)$ and significant \\
\hline
\end{tabular}

Results of Partial Correlation Analysis between Independent and Dependent Variables

The result of the third hypothesis test can be seen in the Table 5 .

Tabel 5. The result of the third hypothesis test

\begin{tabular}{lll}
\hline Independent variable & Regression coefficient & Sig-T \\
\hline Teaching style $\left(\mathrm{X}_{1}\right)$ & 0.422 & 0.000 \\
Learning motivation $\left(\mathrm{X}_{2}\right)$ & 0.201 & 0.000 \\
\hline Constant & 8.178 & \\
R-square & 0.324 & \\
$\mathrm{~F}_{\text {cal }}$ & 33.026 & \\
Sig-F & 0.000 & \\
\hline
\end{tabular}

Results of Regression Analysis between Independent and Dependent Variables

Based on the Table 5, the regression formula was obtained as follows: $\mathrm{Y}=8.178+0.422 \mathrm{X}_{1}+$ $0.201 \mathrm{X}_{2}$. The formula can be described as follows: (a) 8.178 is the constant value if it is not influenced by any variable. It means that if the value of each independent variable, namely Teaching Style $\left(\mathrm{X}_{1}\right)$ and Learning Motivation $\left(\mathrm{X}_{2}\right)$ do not increase or constantly zero, then the Readiness value reaches 8.178; (b) $0.422 \mathrm{X}_{1}$ is the amount of the Teaching Style variable regression coefficient. This value can be interpreted that every 1 unit increase in the Teaching Style variable, then the value of Readiness has increased by 0.422 by assuming the value of other variables is constant. From the regression coefficient, it can be seen that there is a positive and significant relationship between X1 and Y; and (c) $0.201 \mathrm{X} 2$ is 
Jurnal Prima Edukasia, 9 (1), 2021 - 27

Bagas Adi Atma, Fatun Fatimah Azahra, Ali Mustadi, Colomeischi Aurora Adina

the regression coefficient value of the Learning Motivation variable. This value can be interpreted that every 1 unit increase in Learning Motivation, then the value of Readiness will increased by 0.201 by assuming that other variables are constant. Based on the regression coefficient, there is a positive and significant relationship between $\mathrm{X}_{2}$ and $\mathrm{Y}$.

Based on the analysis, it was found that $\mathrm{R} 2$ is 0.324 . It means that the effective contribution of the teaching style variable and learning motivation variable reach $32.4 \%$, or it could be interpreted that the teaching style and the learning motivation variables have a relationship with the learning achievement variable by $32.4 \%$. To calculate the effective contribution of each variable or relative contribution, the study used the Formula 2:

$S E(X) \%$ Beta $_{x} x$ Correlation Coefficient $\left(r_{x y} \times 100 \%\right.$

The detailed can be seen in the Table 6 .

Tabel 6. The Effective Contribution

\begin{tabular}{llll}
\hline Variable & Regression coefficient & Correlation coefficient & R-Square \\
\hline Teaching style $\left(\mathrm{X}_{1}\right)$ & 0.422 & 0.546 & 0.324 \\
Learning motivation $\left(\mathrm{X}_{2}\right)$ & 0.201 & 0.462 & 0. \\
\hline
\end{tabular}

Thus, based on the Formula 2, the contribution of teaching style variable $\left(\mathrm{X}_{1}\right)$ to learning motivation variable is:

SE $\mathrm{X}_{1}=0.422 \times 0.546 \times 100 \%=23.0412 \%$

It means that teaching style variable contributes $23.0412 \%$ to learning achievement. The contribution of the learning motivation variable $\left(\mathrm{X}_{2}\right)$ to learning achievement $(\mathrm{Y})$ is:

SE $\mathrm{X}_{2}=0.201 \times 0.462 \times 100 \%=9.2862 \%$

It means that the learning motivation variable has a contribution of $9.2862 \%$ to student learning readiness with the total contributions of both is the same as the value of R-Square or the total contribution to learning achievement with

$\mathrm{SR}$ total $=\mathrm{SE} \mathrm{X}_{1} \%+\mathrm{SE} \mathrm{X}_{2} \%=23.0412+9.2862=32 \%$

The Relationship between Teaching Style and Learning Achievement

The results of the analysis showed that there is a positive and significant relationship between teaching style and learning achievement with a correlation coefficient of 0.546 . Descriptively, it can be concluded that there is a relationship between teaching style and learning achievement because the correlation coefficient is higher than 0.05 . Based on the correlation coefficient, it can be seen that the contribution of the independent variable to the dependent variable is $23.0412 \%$ meaning that the teaching style contributes or is associated with $23 \%$ of the learning achievement of the fifth-grade students in primary schools in Saptosari sub-district.

Learning achievement is not achieved without any effort. Students' ability to absorb and receive materials does not only depend on the textbooks but also how the teacher improvises in dealing with differences in student backgrounds. In terms of the speed and ability of students to absorb lessons, teachers need teaching styles or teaching methods that are appropriate and able to accommodate most or even all students in the classroom. Active learning which engaging students are one of the teaching techniques that support the learning achievement and it is in line with Hackathorn et al. (2011) who revealed that students get higher test and quiz scores when they are welcome to interact directly with the learning media used by the teacher as confirmed by Lavy (2016) who found that modern teaching styles have greater positive impacts on test scores than traditional teaching styles. Further, it is also suitable for the results of the previous study conducted by Hidalgo-Cabrillana and Lopez-Mayan (2018) in which the use of modern practices in teaching relates to higher learning achievement and the use of traditional practices tends to be detrimental.

However, we cannot generalize that all learning should not use traditional or conventional teaching styles. In some cases, the conventional teaching style can be more effective as found by Bietenbeck (2014) who conducted research on differences between the traditional and modern teaching styles in Mathematics and science subjects in which conventional teaching style has a positive impact on the 
Jurnal Prima Edukasia, 9 (1), 2021 - 28

Bagas Adi Atma, Fatun Fatimah Azahra, Ali Mustadi, Colomeischi Aurora Adina

overall score, while the modern approach provides a less significant increase. However, in terms of question analysis, teaching with a modern approach has more positive impacts as it is not merely to achieve the target score. It indicates that the use of teaching styles should be adjusted to the learning objectives as stated by Ibrahim and Ahmad (2016) that a suitable teaching style will increase learning achievement.

Another research conducted by Rahman (2016) found that there was a positive relationship between the teaching style and learning achievement in which the higher the teaching style, the higher the learning achievement. Therefore, one cannot perceive a certain teaching style negatively it can be adjusted to the conditions of the students. However, teaching style greatly affects the students' learning achievement and future as explained by Chetty et al. (2011) who highlighted the importance of teacher understanding of the teaching process including the teaching style at the earliest stages of how the education process succeeded in increasing student achievement and preventing future dropouts.

\section{The Relationship between Learning Motivation and Learning Achievement}

The result showed that there is a positive and significant relationship between learning motivation and learning achievement with a correlation coefficient of 0.462. Descriptively, it can be concluded that there is a relationship between learning motivation and learning achievement because the correlation coefficient is higher than 0.05 . Based on the correlation coefficient, it can be seen that the contribution of the independent variable to the dependent variable is $9.2862 \%$ meaning that learning motivation contributes or is associated with $9.2 \%$ of the learning achievement of the 5th-grade students of primary schools in Saptosari sub-district.

The result of this current study is in line with the previous studies Ozen (2017) which found that the higher the student's learning motivation, the higher the learning achievement. It can be concluded that learning motivation affects learning achievement. The higher the student's learning motivation, the higher the learning achievement, and vice versa. Another study Sari et al. (2018) found that learning motivation and teaching style have a positive relationship and it also supports the concept that high learning motivation is directly proportional to learning achievement and vice versa. The learning motivation is indicated by the achievement of indicators in learning motivation including being diligent in doing tasks, resilient in facing difficulties, showing interest in adult problems, preferring to work independently, having fun looking for and solving problems, strong willingness in learning, and the allocated time for learning. It is in line with (Bacanlı \& Sahinkaya, 2011; Handarini, 2019; Karagüven, 2012) who agree that learning achievement and learning effectiveness varied according to the students' interests, wants, and needs. Further, Bojović and Antonijević (2017) explained that students' interest, teachers' roles, and family affects students' involvement and motivation in learning.

Nowadays, there is a new term of achievement motivation which further emphasizes the relationship between motivation and achievement. Singh (2011) defines achievement motivation as a subjective and internal psychological drive that allows individuals or students to continue with something they consider valuable and encouraging students to achieve their goals in learning. Further, Steinmayr et al. (2019) explained that students' self-concept plays an important role in predicting students' motivation in learning and influencing their achievement. Even though previously the students had the same grade and the same achievement with others, but their self-concept provides bigger roles in their achievement as concluded by Inah and Khairunnisa (2019) that although learning motivation is not the main requirement in achieving learning achievement, it is a part of intrinsic factors other than interests, intelligence, talents, and cognitive abilities. Further, Sukor et al. (2017) found that two out of six factors of learning motivation empirically influence students' achievement, namely self-efficacy and achievement goals.

The Relationship between Teaching Style and Learning Motivation and Learning Achievement

The result showed that there is a positive and significant relationship between teaching style and learning motivation variables and learning achievement variables with R-square values of 0.324 . Descriptively, it can be concluded that there is a relationship between teaching style and learning motivation variables and learning achievement variables. It means that the simultaneous or joint contribution of two independent variables to the dependent variable is $32.4 \%$ meaning that learning motivation and teaching style contribute $32.4 \%$ to the learning achievement of the 5th-grade students of primary schools in Saptosari sub-district. 
Jurnal Prima Edukasia, 9 (1), 2021 - 29

Bagas Adi Atma, Fatun Fatimah Azahra, Ali Mustadi, Colomeischi Aurora Adina

Based on the results of the data analysis, it can be seen that teaching style and learning motivation have a positive and significant relationship to learning achievement. The result of this study can illustrate that the teaching style contributes $23 \%$ to learning achievement. It means that almost $1 / 4$ of $100 \%$ of learning achievement relates to the teaching style, while $9 \%$ is related to learning motivation. A more internal motivation of each student causes less contribution than other independent variables, but still, have a relationship with the students' learning achievement.

O'Brien (2012) stated that different teaching styles produce different results and students will feel more motivated when teachers have different variations in teaching. Thus, the three examined variables relate to each other as mentioned earlier by Nir and Hameiri (2014) that teaching style and the quality of teaching can have a positive impact on student motivation which results in better academic achievement. It is strengthened by research by Muharam et al. (2019) which emphasizes the relationship between these three variables in which learning motivation can bridge the teaching styles and learning achievement. It indicates that learning motivation and teaching styles are related to learning achievement. Further, Ofosu-amaah et al. (2019) explained that the application of effective teaching styles and motivational strategies do not always lead to good student performance, but it is important to pay attention to consider the suitability of subjects with teaching styles and motivational strategies.

\section{Conclusions}

The result of this quantitative correlational study showed that there is a positive and significant relationship between teaching style and learning achievement with a correlation coefficient value of 0.546 and a relative contribution of $23 \%$, and learning motivation and learning achievement have a correlation coefficient of 0.462 with the effective contribution of $9 \%$. The relationship between teaching style and learning motivation on learning achievement with R-square of 0.324 and the total contribution or effective contribution of $32 \%$. Thus, it can be concluded that the teaching style variable and learning motivation variable have a positive and significant relationship to the learning achievement variable.

\section{References}

Abbas, Q., \& Hussain, S. (2018). Comparative study of teaching styles of various school groups at secondary level in District Chiniot of Punjab. Asian Journal of Education and Social Studies, 2(3), 1-8. https://doi.org/10.9734/AJESS/2018/40360

Ali, R., Ghazi, S. R., Khan, M. S., Hussain, S., \& Faitma, Z. T. (2010). Effectiveness of modular teaching in biology at secondary level. Asian Social Science, 6(9), 49.

Bacanl1, H., \& Sahinkaya, O. (2011). The adaptation study of academic motivation scale into Turkish. Procedia - Social and Behavioral Sciences, 12, 562-567. https://doi.org/10.1016/j.sbspro.2011.02.068

Bietenbeck, J. (2014). Teaching practices and cognitive skills. Labour Economics, 30, 143-153. https://doi.org/https://doi.org/10.1016/j.labeco.2014.03.002

Bojović, I., \& Antonijević, R. (2017). Students' motivation to learn in primary school. Open Journal for Psychological Research, 1(1), 11-20. https://doi.org/10.32591/coas.ojpr.0101.02011b

Çelen, B., Kariv, S., \& Schotter, A. (2010). An experimental test of advice and social learning. Management Science, 56(10), 1687-1701. https://doi.org/10.1287/mnsc.1100.1228

Chetty, R., Friedman, J. N., Hilger, N., Saez, E., Schanzenbach, D. W., \& Yagan, D. (2011). How does your kindergarten classroom affect your earnings? Evidence from project star. Quarterly Journal of Economics, 126(4), 1593-1660. https://doi.org/10.1093/qje/qjr041

Cudney, E. A., \& Ezzell, J. M. (2017). Evaluating the impact of teaching methods on student motivation. Journal of STEM Education, 18(1), 32-50.

https://www.jstem.org/jstem/index.php/JSTEM/article/view/2197

Frunză, V. (2014). Implications of teaching styles on learning efficiency. Procedia - Social and Behavioral Sciences, 127(1979), 342-346. https://doi.org/10.1016/j.sbspro.2014.03.268

Gafoor, K. A., \& Babu, H. (2012). Teaching style: A conceptual overview. In Teacher education in the new millennium (pp. 55-69). APH.

Hackathorn, J., Garczynski, A. M., Blankmeyer, K., Tennial, R. D., \& Solomon, E. D. (2011). All 
Jurnal Prima Edukasia, 9 (1), 2021 - 30

Bagas Adi Atma, Fatun Fatimah Azahra, Ali Mustadi, Colomeischi Aurora Adina

kidding aside: Humor increases learning at knowledge and comprehension levels. Journal of the Scholarship of Teaching and Learning, 11(4), 116-123.

Handarini, D. M. (2019). Kontribusi faktor-faktor non-kognitif pada prestasi belajar siswa sekolah menengah pertama. Psychology, Evaluation, and Technology in Educational Research, 1(2), 62. https://doi.org/10.33292/petier.v1i2.22

Hidalgo-Cabrillana, A., \& Lopez-Mayan, C. (2018). Teaching styles and achievement: Student and teacher perspectives. Economics of Education Review, 67, 184-206.

https://doi.org/10.1016/j.econedurev.2018.10.009

Ibrahim, I., \& Ahmad, A. (2016). Teaching styles preferred by students on their achievement in history subject. IOSR Journal Of Humanities And Social Science (IOSR-JHSS), 21(6), 47-53. https://doi.org/10.9790/0837-2106054753

Idhaufi, N. L. M., \& Ashari, Z. M. (2017). Relationship between motivation and teachers' teaching style among secondary school students' in Kulai. Man in India, 97(12), 299-307.

Inah, E. N., \& Khairunnisa, A. (2019). Hubungan motivasi belajar dengan prestasi belajar bahasa Arab mahasiswa bidikmisi. Al-TA 'DIB, 12(1), 36. https://doi.org/10.31332/atdb.v12i1.1220

Karagüven, M. H. Ü. (2012). The adaptation of academic motivation scale to Turkish. Educational Sciences: Theory and Practice, 12(4), 2611-2618.

Lavy, V. (2016). What makes an effective teacher? Quasi-experimental evidence. CESifo Economic Studies, 62(1), 88-125. https://doi.org/10.1093/cesifo/ifv001

Muharam, L. O., Ihjon, I., Hijrah, W. O., \& Samiruddin, T. (2019). The effect of teaching style on students' motivation and academic achievement: Empirical evidence from public senior high school in konawe selatan regency. International Journal of Scientific and Technology Research, 8(9), 1934-1938.

Nir, A. E., \& Hameiri, L. (2014). School principals' leadership style and school outcomes: The mediating effect of powerbase utilization. Journal of Educational Administration, 52(2), 210 227. https://doi.org/10.1108/JEA-01-2013-0007

O’Brien, M. (2012). Fostering a creativity mindset for teaching (and learning). LEARNing Landscapes, 6(1), 315-333. https://doi.org/10.36510/learnland.v6i1.589

Ofosu-amaah, E., Kpeyibor, P. F., Boakye, A., Semordey, C. R., \& Ato-davies, A. (2019). Teachers' teaching styles and motivational strategies: It's impact on the academic performance of students in Ghana. Journal of Social Science and Humanities, 5(3), 232-243.

http://www.aiscience.org/journal/paperInfo/jssh?paperId=4486

Ozen, S. O. (2017). The effect of motivation on student achievement. The Factors Effecting Student Achievement: Meta-Analysis of Empirical Studies, 4(1), 35-56. https://doi.org/10.1007/978-3319-56083-0_3

Rahman, M. H. (2016). Pengaruh model pembelajaran dan gaya mengajar guru tehadap prestasi belajar siswa pada mata pelajaran PKN. Jurnal Penelitian Dan Pendidikan IPS (JPPI), 10(3), 337-344. http://ejournal.unikama.ac.id/index.php/JPPI/article/view/1684

Sardiman AM. (2007). Interaksi dan motivasi belajar mengajar. Rajagrafindo Persada.

Sari, S. F., Yusmansyah, Y., \& Utaminingsih, D. (2018). Hubungan motivasi belajar dengan prestasi belajar siswa SMP Negeri 1 Sukadana Kabupaten Lampung Timur. ALIBKIN (Jurnal Bimbingan Konseling), 5(6), 1-12.

Sharma, D., \& Sharma, S. (2018). Relationship between motivation and academic achievement. International Journal of Advances in Scientific Research, 4(1), 01. https://doi.org/10.7439/ijasr.v4i1.4584

Singh, K. (2011). Study of achievement motivation in relation to academic achievement of students. International Journal of Educational Planning \& Administration, 1(2), 161-171.

Steinmayr, R., Weidinger, A. F., Schwinger, M., \& Spinath, B. (2019). The importance of students' motivation for their academic achievement-replicating and extending previous findings.

Frontiers in Psychology, 10(JULY). https://doi.org/10.3389/fpsyg.2019.01730 
Jurnal Prima Edukasia, 9 (1), 2021 - 31

Bagas Adi Atma, Fatun Fatimah Azahra, Ali Mustadi, Colomeischi Aurora Adina

Sukor, R., Ayub, A. F. M., Zawawi, N., \& Nor-Khaizura, M.-A.-R. (2017). Influence of students' motivation on academic performance among non-food science students taking food science course. International Journal of Academic Research in Progressive Education and Development, 6(4), 104-112. https://doi.org/10.6007/ijarped/v6-i4/3528

Vărăşteanu, C.-M., \& Iftime, A. (2013). The role of the self-esteem, emotional intelligence, performance triad in obtaining school satisfaction. Procedia - Social and Behavioral Sciences, 93, 1830-1834. https://doi.org/10.1016/j.sbspro.2013.10.125

Williams, K. C., \& Williams, C. C. (2011). Five key ingredients for improving student motivation. Research in Higher Education Journal, 11, 1-23.

http://scholarsarchive.library.albany.edu/math_fac_scholar 